\title{
Brazil and the institutionalization of South America: from hemispheric estrangement to cooperative hegemony
}

\author{
O Brasil e a institucionalização da América do Sul: \\ do estranhamento hemisférico à hegemonia cooperativa
}

CARLOS GUSTAVO POGGIO TEIXEIRA*

Rev. Bras. Polit. Int. 54 (2): 189-211 [2011]

\section{Introduction}

This article examines the origins of the Free Trade Area of the Americas (FTAA) proposal, showing that the idea of a hemispheric free trade area was launched at the same time that each of the regional subsystems in the Western hemisphere were consolidating their own regional institutions around core regional states: North American Free Trade Agreement (NAFTA) in North America, and Common Market of the South (Mercosur) in South America. It shows that the United States saw a hemispheric free trade agreement as an extension of NAFTA and consequently Mercosur was soon perceived as a nuisance by US policymakers.

Likewise, Brazil demonstrated clear reservations regarding the establishment of a free trade area in the Americas since the beginning, and was clearly unsupportive in regard thereto, a feeling that was not initially shared by its neighbors. Therefore, the interests of Brazil and the United States clearly clashed, and given the disparities in power between the two countries, it would be reasonable to expect that the final outcome would favor the latter's view. Brazil's strategy was to lead the formation of a South American bloc aiming to institutionalize South America and increase the costs for the establishment of the FTAA. This article argues that Brazil's strategy of leadership was facilitated by the United States' lack thereof.

The article also shows that one economic crisis in each subregion in the Americas-Mexico in North America, and Argentina in South America-acted as catalysts that reinforced subsystemic dynamics and made even more evident the separation between these two regional subsystems. The combination of these factors led to the eventual demise of the FTAA, with Brazil increasingly seeking

\footnotetext{
* Professor de Relações Internacionais da Pontifícia Universidade Católica de São Paulo (PUC-SP) (cgpteixeira@gmail.com).
} 
to institutionalize the South American subsystem and the United States resorting to bilateral agreements with like-minded countries in that regional subsystem.

\section{NAFTA and Mercosur}

A few months after the United States signed a free trade agreement with Canada in the late 1980s, Mexican President Carlos Salinas approached his US counterpart George Bush in the beginning of 1990 with the idea of a free trade agreement between the two countries. Initially, this proposal "came as a surprise" to the Bush administration (Mayer 1998, 41), since its top trade policy priority was the conclusion of the so-called Uruguay Round of the General Agreement on Tariffs and Trade (GATT), which would eventually lead to the creation of the World Trade Organization (WTO). In spite of the initial hesitation, the Bush administration soon embraced the idea, as an agreement with Mexico was seen from Washington's point of view as "part of an overall strategy of building" a "continental base" centered on the United States (Mayer 1998, 42). Therefore, in August 1990, President Salinas "formally requested a free trade agreement with the United States" (ibid., 46). The Canadians, who had just fought a fierce domestic battle over the conclusion of their own free trade agreement with the United States, did not initially want to get involved; but realizing that it had little to gain by staying on the sidelines, the Canadian government later decided that it would be better to participate and consequently they joined the negotiation in early 1991 . Hence, what was initially a bilateral negotiation became a trilateral one, and thus was created the basis for the treaty known as North American Free Trade Agreement (NAFTA). More than just a free trade agreement, at the political level NAFTA allowed the US government to reaffirm the principles of international free trade "as a symbol and a reality of a new economic order ushered by the United States as part of its victory in the Cold War" (Dominguez and Castro 2009, 26). Indeed, in the midst of the negotiations with Mexico, the Bush administration unveiled its Enterprise for the Americas Initiative (EAI), a hemispheric program of which one of the central aims was the extension of free trade to the whole of the Americas. Within the framework of a "new world order," NAFTA would thus be just a strategic "continental base" from which the United States would lead the post-Cold War world, beginning by reaffirming its leadership in the Western Hemisphere. Therefore, US interest in hemispheric integration could be interpreted as going beyond the notion of economic benefits given the "possibilities it offers for the reinforcement of the structural and ideological foundations of US hegemony, consistent with its parallel global strategies" (Phillips 2003, 331).

The vision of a hemispheric free trade area put forth by President Bush was embraced by subsequent US administrations until its demise in the mid-2000s during the second President Bush administration. While the first President Bush 
launched the overall idea and initiated NAFTA, the Clinton administration wrapped up NAFTA and made the FTAA one of its top foreign policy priorities in Latin America, an approach that was followed by his successor. According to one of the participants in the initial stages of FTAA, there was a growing feeling in the Clinton administration in 1992 that a hemispheric summit "would be a logical follow-up to NAFTA" (Feinberg 1997, 58). President Clinton had the expectation that the conclusion of NAFTA would enable the United States to "use the Mexican precedent to go into the whole rest of Latin America" (ibid., 66). Accordingly, in 1993, the Clinton administration announced that a summit would take place in Miami in December 1994 to discuss a number of hemispheric issues. During the Miami Summit, which was attended by all countries in the hemisphere except Cuba, the participating countries announced the goal of a hemispheric free trade area to be established by the year 2005, thus marking the beginning of the negotiations of the FTAA.

The year the Miami Summit convened was particularly relevant for matters of hemispheric integration. In January 1994, the North American Free Trade Agreement, which had been approved by the US Congress in late 1993, came into force. In December that same year, a few days after the Miami Summit, Argentina, Brazil, Paraguay, and Uruguay signed in Brazil the Protocol of Ouro Preto, which complemented the 1991 Treaty of Asunción and established the institutional basis of the Southern Common Market (Mercosur), thus giving Mercosur legal personality of international law and providing it with effective actor capabilities in the international arena. ${ }^{1}$ On the first day of 1995, the four countries of Mercosur introduced a common external tariff covering about 85 percent of the goods traded within the bloc, thus transforming Mercosur into a customs union, although an imperfect one given the fact that some of the goods were outside the scope of the tariff. From an economic standpoint, Mercosur has been the second largest trading bloc in the hemisphere after NAFTA in terms of combined GDP, and the fourth in the world behind the European Union, NAFTA, and the Association of South East Asian Nations (ASEAN). Therefore, any meaningful regional integration in the Western Hemisphere would have to accommodate the reality of Mercosur-to deal with it or to do away with it. From the point of view of the United States, hemispheric integration meant the absorption of Mercosur into an enlarged NAFTA with the United States at the center. In fact, members of the Clinton administration expressed a number of times that Mercosur was seen as "harmful" to the FTAA and "a threat to hemispheric regionalism." (Bernier and Roy 1999, 69; Carranza 2000, 124; Bandeira 2004, 133-35; Smith 2010, 189).

Because of the prospects of altering the status quo in the South American subsystem, this scenario was feared by Brazil, which held suspicions regarding

1 Even though the personal preferences of the author of this article would advise him to use the Portuguese term "Mercosul," the use of the Spanish form "Mercosur" is more widely employed in the literature in English. 
the establishment of free trade in the Americas since the beginning and saw it as an "obstacle to the designs of Brazilian leadership within the regional order" in South America (Cervo and Bueno 2008, 488). In fact, the Brazilian Foreign Minister during the Cardoso administration described the FTAA as a tool to consolidate US "economic preponderance in the continent" and as a "potential threat" to Brazil, therefore mirroring verbatim the Clinton administration's view of Mercosur (Lampreia 2010, 183, 189). When the Enterprise for the Americas Initiative was unveiled in 1991, Brazil was clearly "the least enthusiastic among the participating countries to move forward on hemispheric integration" (Rompay 2004, 120). In fact, Brazilian official position towards hemispheric free trade has been, like the US official position, considerably consistent through time, permeating four different administrations from different political outlooks. Basically, Brazil's strategy has been one of securing and reinforcing its position within the South American subsystem in order to avoid its absorption by an allencompassing hemispheric subsystem. Within this context, the establishment of Mercosur with the Treaty of Asunción in 1991 was a key strategic component. As soon as George Bush announced his Enterprise for the Americas Initiative, the Collor de Mello administration in Brazil responded that it would only negotiate a hemispheric agreement within the $4+1$ framework, i.e. the four countries of the recently created Mercosur would take a joint position when negotiating with the United States. In 1993, the same year that NAFTA was approved by the US Congress, the Itamar Franco administration made a proposal for a South American Free Trade Area (SAFTA). These early efforts demonstrate the Brazilian concern in securing a "continental base" for itself in order to counter the prospects of a US commercial offensive in South America. In fact, when Cardoso was the Brazilian Foreign Minister, he spoke about the notion of a "South American platform" (Cardoso 1994, 185) and later, as president, Cardoso referred to Mercosur as "a pole from which we will organize the South American space" (Cardoso 1998, 127). Mercosur was thus seen as a hub from which Brazil would build an alternative pole of attraction in the hemisphere, and as a result would attempt to create obstacles for greater US penetration in the South American subsystem. As will be shown below, these efforts were continued and then deepened in subsequent Brazilian administrations.

Brazilian official strategy towards hemispheric free trade was, not surprisingly, far from enjoying unanimity in South America. As a matter of fact, two of the biggest powers in the region, Argentina and Chile, were very enthusiastic about the possibility of coming to an agreement with the United States as early as possible, ideally before the 2005 deadline. In a complete reversal of its historically contentious stance towards the United States, the Argentine government became one of its most fervent supporters during the greater part of the 1990s. Distant and often confrontational towards US foreign policy initiatives during most of its history, Argentina undertook a complete shift in that historical position under the 
administration of Carlos Menem and sought to establish, in the now legendary words of Menem's Foreign Minister, "carnal relations" with the United States (Munck 1992, 210). Perhaps the best indication of this renewed relationship is the fact that Argentina dispatched naval vessels to the 1991 Gulf War, the only Latin American country to do so. In 1998, the United States reciprocated Argentinean cooperation by designating Argentina as a "major non-NATO ally," also the only Latin American country to have this distinction. ${ }^{2}$ Within this context, a trade agreement with the United States was a logical extension of Argentinean foreign policy, which even entertained the possibility of an accession to NAFTA. However, Argentina could not freely sign a bilateral agreement with the United States without leading to the demise of Mercosur as a customs union and creating problems with Brazil, which was a more important market for Argentina than the United States: in 1994, the year before the Ouro Preto Protocol took effect, Argentina exported twice as much in value to Brazil than to the United States (IADB 2011). ${ }^{3}$ Therefore, by locking in Argentina through Mercosur, Brazil could with reasonable success contain Argentinean initial enthusiasm during the early stages of the FTAA negotiations. On the other hand, Argentinean and other South American countries' eagerness for such an agreement was an important reason why Brazil could not simply negate to negotiate the US-proposed FTAA, as it would leave Brazil isolated in the region it aspired to influence.

Conversely, the constraints that applied to Argentina were not valid for Chile. Chile was not part of Mercosur and the United States was a much more important market for Chilean exports than Brazil. Moreover, Chile has had a relatively open economy and international trade has been a key component of its development strategy. In fact, Chile had been seeking a free trade agreement with the United States since the early 1990s, and after Mexico it was next in line to negotiate such an agreement. During the Miami Summit in 1994, Chile was officially invited to join NAFTA and was hailed by the Canadian Prime Minister as the fourth "amigo" in the North American agreement. ${ }^{4}$ Following the official invitation, negotiations for Chilean accession to NAFTA were formally initiated in 1995. Nevertheless, the Clinton administration had one important domestic obstacle after 1994-the lack of the so-called "fast track" authority to negotiate free trade agreements. This bureaucratic detail that, up until then, was little known outside the circle of trade experts, turned out to be the centerpiece of the problems facing the United States during the negotiations of the FTAA, and made it considerably easier for Brazil to enforce its agenda in South America.

2 Brazil, "wary of Washington's potentially overbearing influence" in South America, had a "notably negative" reaction (Fauriol and Perry 1999, 33).

3 By 2009, Argentina exported to Brazil four times more than to the United States (IADB 2011).

4 "We have been the Three Amigos. Now we will be the Four Amigos," proclaimed Canadian Foreign Minister Jean Chretien (Rohter 1997). 
According to the US Constitution, it is the responsibility of the Congress to regulate matters of foreign trade. Because of the possibility that Congress may change an agreement previously signed by the executive to the point that it becomes entirely distinct from what was originally agreed upon by the parts, Congress may grant the President a special authority that became known as "fast track," which gives greater autonomy to the executive to sign free trade agreements, leaving Congress the possibility to either accept or reject it without amendments. Additionally, fast track rules require the Congress to vote within ninety days after the bill is submitted by the president. NAFTA was approved by the US Congress under fast track provisions, but that expired in 1994. For the remainder of his administration, President Clinton unsuccessfully tried to reinstate fast track authority after 1994 in order to promote the FTAA agenda. As the difficulty that the Clinton administration had in obtaining fast track became clear, the agreement with Chile lost momentum, and by 1996 Chile had all but abandoned any hopes of joining NAFTA. The Chilean President Eduardo Frei was reported to have "considered the United States an unreliable ally" (Feinberg 1997, 177). As the difficulties in joining NAFTA became clear, "Chilean advocates of expanding ties with the Southern Cone gained ground" (Haggard 1998, 318). Indeed, in October 1996, Chile joined Mercosur as an associated member, as it became, in the words of Henry Kissinger, "tired of waiting for the long-promised access to NAFTA" $(2001,96)$. By 1997, after Chile had already signed free trade agreements with both Mexico and Canada, as well as with Mercosur and other South American countries, the Chilean Foreign Minister declared that NAFTA ascension no longer had "either the urgency or the importance it had in 1994" (Rohter 1997).

Therefore, whereas Brazilian leadership was an important factor to explain the lack of an early agreement in the case of Argentina, in the case of Chile the main explanation should lie with US lack of leadership; not so much because of an unwillingness to lead, but more because of incapacity to do so due to domestic dynamics. It is this combination of Brazilian obstructionism and US inability to provide the necessary leadership that provides the better explanation for the failure of the FTAA. In other words, Brazilian strategy of leading a South American bloc was greatly facilitated by US lack of leadership in the process. The cases of Argentina and Chile during the first couple of years of FTAA negotiations provide a clear illustration of this claim.

\section{Launching the FTAA}

As indicated above, since the very beginning of the negotiations for the establishment of a Free Trade Area of the Americas two major views regarding the character of hemispheric integration clashed. These two views were represented by the two biggest economies in the hemisphere and the two major powers within their respective regional subsystems: the United States and Brazil. These different 
perspectives were rooted in the fact that the US view of the international system after the Cold War clashed with the Brazilian view of preserving its role in South America. As noted above, while for the United States an expansion of NAFTA to the whole hemisphere formed the basis of its approach to hemispheric integration and was seen as part of the broader US view of a new world order, the Brazilian priority was to consolidate its position in the South American subsystem, which, from the point of view of Brazilian policy-makers, would be jeopardized by a hemispheric free trade area.

Brazil's concern about regional leadership was unsurprisingly not shared by the other South American countries, which, as exemplified by the cases of Argentina and Chile mentioned above, generally greeted the 1994 Miami Summit with great enthusiasm. In contrast, the Brazilian Foreign Minister signalized Brazilian skepticism regarding the Miami meeting and "warned that the region had overly high expectations of the summit" (Feinberg 1997, 115). These dynamics were already patently clear when US Vice-President Al Gore made a trip to Argentina, Bolivia, and Brazil in 1994 to promote the Miami Summit, scheduled for the end of that year. Like Argentina, Bolivia also demonstrated great interest in the proposal for a hemispheric free trade area and even suggested that it should be reached by the year 2000 instead of by the original 2005 goal. On the other hand, Gore's meeting with Brazilian representatives revolved around recognizing Brazil's "stature in hemispheric affairs" and "little discussion of the summit agenda as such" (ibid., 109). The themes that Gore discussed in Brazil evidently reflected what the true Brazilian concerns were at the time.

As the preparations for the Miami Summit went forward, it became increasingly clear that accommodating the different views of the United States and Brazil would be a central issue in the negotiations for a free trade area in the hemisphere. Because it could not simply block the negotiations as it was in a relatively isolated position, Brazilian strategy was to "render the plan of action more modest in its ambitions, less exact in its objectives, less specific in its timetables, and less accountable in its implementation" (ibid., 146). In fact, not only did Brazil actively participate in the negotiations - its delegation in Miami was second in number only to the United States, which is an indication of the interest that the Brazilian government had in the issue. According to one US negotiator, "the heart of the drama of Miami was Brazil's struggle to establish itself as the interlocutor for South America," and a major concern of Brazil was to introduce changes in the final text "aimed at lessening future US influence and leaving the integration process less carefully scripted" (ibid., 195, 134). Contrary to most of the other countries, Brazil wanted to gain time in order to consolidate and enlarge Mercosur, in order to strengthen its own position vis-à-vis the United States, and only then attempt to strike a "grand bargain between NAFTA and Mercosur (that is, between the United States and Brazil)" (ibid., 180). In spite of Brazilian efforts to bypass the mention of a date certain, the Miami Declaration stuck with the 2005 goal 
of hemispheric free trade, reflecting the view of the majority of the countries in Latin America.

Therefore, by the end of the Miami Summit, even though the differences between Brazil and the United States were clear, it was the latter that got the upper hand and dictated the pace of the negotiations at the onset. This could obviously be understood as a logical corollary of the overwhelming disparities in all dimensions of power between the two countries, which seemed to offer support for the conventional analysis of US hegemony in Latin America predicting that " $[\mathrm{b}]$ ecause of US power, NAFTA is probably a closer approximation to the evolving FTAA than is Mercosur" (Katzenstein 2005, 233). In fact, many studies that attempted to forecast the "economic and business outcomes of the FTAA" commonly accepted the apparently obvious premise that the FTAA "is going to build on the basic principles of NAFTA" (Rugman 2004, 90). As soon as it was established, NAFTA was quickly presented even as a theoretical model of "hemispheric regionalism" as opposed to a "Latin American regionalism" (Hurrel 1995; Atkins 1996). However, the actual facts do not corroborate the assumption that US power would inevitably bring into being the US view of hemispheric integration. This gap between a proposed US policy and the actual outcome begs for an explanation. Evidently, one could concentrate only on domestic factors and conclude that this gap can be adequately explained by the troubles that the Clinton administration had in obtaining fast track authority from Congress. Although one can be satisfied with this explanation — and domestic factors were certainly critical—it can also be argued that it is an incomplete one. Indeed, even when the Bush administration finally got the fast track - then renamed "Trade Promotion Authority" (TPA)-between 2002 and 2007, thus including the 2005 deadline for the completion of the FTAA, still no hemispheric NAFTA came into being. Instead, the Bush administration used the TPA to negotiate a series of bilateral trade agreements with countries in the region, hence outside the scope of a comprehensive hemispheric framework. Beyond domestic explanations, it is necessary to understand how subregional interactions contributed to the developments of the FTAA negotiations after the Miami Summit.

\section{Mexico and Argentina: a tale of two crises}

A few days after the Miami Summit, on December 20, 1994, and following a series of political shocks during that year that "bruised public confidence in Mexico's political and economic stability," a sudden devaluation of the Mexican peso caused a profound economic crisis in that country, with impacts all over Latin America (Whitt Jr. 1996, 4). Having just signed a free trade agreement with Mexico and with high stakes in its financial stability, the United States acted swiftly in leading the elaboration of an international rescue plan for its southern 
neighbor. The final package totaled about US\$50 billion, with the United States and the International Monetary Fund (where the United States has the largest share of votes) contributing with more than two-thirds of this value (New York Times 1995). Although the rescue package ended up being successful and the Mexican economy recovered from the crisis by 1996, the costs of rescuing Mexico reduced much of the enthusiasm in Washington for further agreements with other Latin American countries, which greatly contributed to the difficulties of the Clinton administration in obtaining fast track authority after 1994. Indeed, according to some analyses, the Mexican crisis represented a "lethal blow" for the FTAA (Roett 1999, 112). This US paralysis offered an opportunity for Brazil to push its agenda in South America, and while "U.S. congressional approval of any post-NAFTA trade agreements had been put in jeopardy by the Mexican crisis, Mercosur initiated negotiations with Bolivia, Venezuela, and Chile" (Hirst 1999, 40). By 1997, both Chile and Bolivia — which were two of the most enthusiast countries regarding the FTAA — had been added to Mercosur as associate members, thus starting a process of regional institutionalization that, as will be shown below, would eventually lead to something resembling the original Brazilian scheme of a South American Free Trade Area.

Therefore, by the time of the Second Summit of the Americas in 1998, in Santiago, Chile, which officially launched the negotiations of the FTAA, there was a clear change in the mood from four years earlier. While in North America the United States had been intimately involved in rescuing Mexico from financial collapse, in South America, Brazil—as President Cardoso had remarked—was actively seeking to "organize the South American space" by using Mercosur as "the pole of attraction for a future South American Free Trade Area" (Carranza 2000, 106). As the United States, for better or for worse, became more involved in Mexican affairs and faced the domestic consequences of such involvement, a "leadership vacuum" was created in South America which "was quickly filled by Brazil reaching out to other South American countries so as to establish SAFTA to accumulate negotiating power" in order to deal with the United States (ibid.). A clear illustration of this change in mood that facilitated Brazilian strategy is the fact that Chile was aligned with Mercosur at the negotiating table in Santiago.

Consequently, at the Santiago Summit in 1998, the scenario was much more favorable to Brazil in comparison to Miami in 1994, as Brazil had achieved its key objective of negotiating the FTAA not in a country-by-country basis but "between a South American bloc, led by Brazil, and a North American bloc, led by the United States" (Carranza 2000, 127). This notion of the FTAA as following the principle of "building blocs," that is, integration within the existent regional blocs, had been a key component of the Brazilian strategy, which was clearly much more focused on first securing its position in South America before reaching any agreement that included the United States. Hence, as the negotiations were formally launched in Santiago, what initially seemed as a process of hemispheric integration centered on 
NAFTA increasingly became a process of hemispheric integration with two poles of attraction, one in North America and the other in South America. In a matter of just four years, "the roles of US and Brazil in the FTAA negotiations had been reversed" (ibid., 131). According to one US analyst at the time, "[t]he balance of hemispheric power shifted at the Santiago summit" as "the United States had lost the initiative in the FTAA negotiations" and had "become a mere bystander in a hemispheric process of trade liberalization in which Brazil now is setting the pace and direction of negotiations" (Sweeney 1998).

Another financial crisis would soon have an impact on the negotiations of hemispheric integration in the Americas. Similarly to what had happened to Mexico after the Miami Summit, a few months after the Santiago Summit, Brazil would also be forced to abruptly devalue its currency at the beginning of 1999 . Argentina, which at the time had a currency regime fixed by law to the value of the US dollar, soon suffered the consequences of the Brazilian devaluation and, after a brutal economic, political, and social crisis, was also eventually forced to abandon its fixed exchange rate in January 2002. Therefore, between 1999 and 2001, while Brazil had a flexible exchange rate, Argentina stuck to a fixed exchange rate, which created significant macroeconomic imbalances between the two major Mercosur members. These events had dreadful economic effects on Mercosur and created "a series of noisy trade disputes" between Brazil and Argentina, with Argentina resorting to a number of protectionist measures incompatible with Mercosur rules in order to compensate for the disparities in the exchange rates between the two countries, which had made Argentinean exports to Brazil less competitive (Rohter 2001). Intra-Mercosur exports, which had quadrupled between 1994 and 1998 , from around US\$6 bi11ion to US $\$ 20$ billion, dropped to US $\$ 10$ billion in 2002 (IADB 2011). Thus, while Mercosur was seen as a great success by the time of the Santiago Summit in 1998, at the next gathering of the heads of state and government of the Americas, which was held in Quebec, Canada, in 2001, the South American bloc had effectively lost much of its economic rationale and faced its darkest period, with many analysts proclaiming its imminent demise. ${ }^{5}$ However, while the 1999-2001 crises underlined the economic limitations of Mercosur, the eventual survival of the bloc and the subsequent events underscored the importance of its political dimension, particularly to Brazil.

But before examining the factors behind the survival of Mercosur even after it seemed to have collapsed, it is crucial to investigate how the Argentinean crisis made evident pressures at the regional subsystemic level. Similarly to the Mexican crisis, which brought Mexico and the United States closer together and at the same time decreased US eagerness for hemispheric integration, the Argentinean crisis ended up having comparable political effects in respect to the South American subsystem - as Argentina recovered from its economic crisis, it became closer to

5 See, for example, Stratfor (2001), Carranza (2003), and Preusse (2004). 
Brazil and far less enthusiastic about the FTAA. In other words, both the Mexican and the Argentine crises worked as catalysts for reinforcing patterns of relationships within their respective regional subsystems, thus demonstrating the difficulties of overcoming such patterns. This assessment becomes even more apparent when one considers that both Mexico and Argentina had similar foreign policy trajectories in their relations with the United States-from a generally cool and sometimes confrontational policy during most of their history, to an abrupt shift in the late 1980s and early 1990s as both sought to develop a closest-as-possible policy. While this shift may be explained both by domestic factors as well as a response to the changes in the international system, the regional subsystemic approach can help explain the differences in outcome of these two similar policies. Examining the distinct interactions that followed the Argentinean economic crisis in contrast to the Mexican economic crisis a few years earlier uncovers how subsystemic dynamics were at play.

At least two factors can be pointed out to explain why the Argentinean crisis had the effect of bringing Brazil and Argentina closer together instead of further apart, as seemed to be the trend during the several trade disputes between Argentina and Brazil after 1999. One factor was that the economic crisis led Argentinean policy makers to the realization that the policy of "carnal relations" with the United States announced in the early 1990s seemed to have produced few tangible results. In contrast to its behavior during the Mexican crisis a few years earlier, when the United States quickly acted to bail out its southern neighbor, Argentina was treated with "indifference and lack of assistance" by Washington (Rohter 2002). This evident dissimilarity in US attitudes accelerated a process of reorientation in Argentina's foreign policy towards a gradual distancing from Washington, which had in fact been taking place since 1997, by the end of the Menem administration (Tokatlian 2000). With the short-lived era of automatic alignment with the United States over, Brazil emerged as the "principal beneficiary" of US unresponsiveness to Argentina's economic debacle, as Argentina openly refocused its foreign policy in improving relations with its most important neighbor (Rohter 2002). Realizing an opportunity to reinforce its position in South America, Brazil, "in stark contrast to the perceived callous indifference of the United States to Argentina's plight," took a series of unilateral measures beginning in 2002 in order to facilitate Argentinean exports (O'Keefe 2009, 96-97). In addition, all the Mercosur countries, including the associated members Chile and Bolivia, convened an extraordinary meeting in Buenos Aires to offer their support and request financial assistance to Argentina from international institutions. Therefore, as Mario Carranza $(2004,326)$ asserts, in spite of the negative effects of the Argentinean crisis on Mercosur, it "had a positive political impact" since the "absence of US leadership to deal with the crisis strengthened political solidarity among the Mercosur partners."

The second factor accounting for why the Argentinean crisis ultimately had the effect of bringing Argentina closer to Brazil while it simultaneously became 
far less enthusiastic about the need for a FTAA is, in a sense, intimately related to the first: the fact that the extension and depth of the crisis that hit Argentina led to a "significant reassessment of the country's power position in the regional, hemispheric and multilateral systems" (Mera 2005, 134). The immediate effect of this "downward revision of Argentina's power potential" was that it increased the "incentives for bandwagonning with its stronger neighbour in order to increase its leverage in external negotiations" (ibid.). In other words, the Argentinean crisis had such a psychological impact on policy makers and civil society alike as to remove Argentinean pretensions of joining the developed North—as symbolized by its inconsequential granting as a "major non-NATO ally" during the early 1990s_-and to "South-Americanize" Argentinean foreign policy. This reorientation meant that Argentina's foreign policy had become closer to Brazil's, which had been constantly seeking to establish a united South American front to negotiate the FTAA.

The above discussion helps to understand Mercosur's endurance in spite of its near collapse. The basic reason seems to be the fact that Mercosur "has always been about more than free trade," with important political and also military dimensions (Carranza 2004, 325-26). While Argentina, as well as Paraguay and Uruguay, initially saw the commercial aspects of Mercosur as the major factor for joining the regional trading bloc, for Brazil, whose economic benefits from Mercosur are less significant, the main motivation "would appear to be its ambition to be a regional power" (Weintraub 2000, 28). Successive Brazilian administrations have consistently valued Mercosur not merely for its potential economic benefits, but as a "potent symbol of Brazil's ambition to be a leader of South American unity" (Handelman 2001). Before the Quebec meeting in 2001, at the height of the crisis between Brazil and Argentina, President Cardoso set the tone of Brazil's position declaring that "Mercosur is a destiny for us, while the FTAA is an option" (Rohter 2001). Without accounting for the strategic considerations behind Brazilian support for Mercosur, in terms of the consolidation of a sphere of influence in South America, it becomes definitely problematic to explain its resilience. In fact, the survival of Mercosur after bitter trade disputes between Brazil and Argentina following their financial crises can only be understood in the context of the political approximation that they contributed to bring about, even as it accelerated the shift in Argentinean foreign policy away from Washington and closer to Brasília. In other words, Mercosur's survival "reflected a convergence of foreign policy or 'strategic' incentives between the governments of Argentina and Brazil" that had been initiated in the late 1990s (Mera 2005, 129). Also important is the fact that after both countries were forced to adopt a fluctuating exchange rate, this "strategic convergence" was followed by a gradual macroeconomic convergence, which removed much of the rationale behind their trade disputes. Indeed, intraMercosur exports grew every single year after hitting the bottom in 2002, from US $\$ 10$ billion to a record US\$41 billion in 2008 (IADB 2011). 
Hence, the resilience of Mercosur can be explained because it is not an artificial arrangement with no basis on actual interactions but an institutional translation of a regional subsystemic reality - the same way that NAFTA is. ${ }^{6} \mathrm{~A}$ putative FTAA, on the other hand, would have to either reflect or create new patterns of relationships in order to overcome subsystemic pressures and be an effective and enduring institution. Because the FTAA did not reflect actual patterns of interactions between the North and South American regional subsystems, it would have probably required a combination of specific political circumstances in order to bear the necessary costs to make it happen. Another possibility was that an unexpected disturbance in the regional subsystems in the hemispheresuch as a financial crisis in a key regional state-could set in motion potentially self-reinforcing subsystemic dynamics, making it even more difficult or costly to create new patterns of relationship necessary for the establishment of an enduring hemispheric arrangement.

\section{Brazilian "cooperative hegemony"}

Therefore, during the course of their interactions following the lofty goals enunciated at the Miami Summit in 1994, it became clear that neither US power nor the enthusiasm with which the FTAA proposal was initially received in Latin America would necessarily translate into a comprehensive hemispheric integration scheme centered on the United States. The difficulties in obtaining fast track authority and the discrepancies in behavior between the Mexican and Argentinean crises seemed to signal that the United States was either unwilling or unable to bear the costs of subsystemic change through the establishment of fundamentally new patterns of interactions. On the other hand, Brazilian strategy was basically one of increasing the costs of FTAA through the gradual consolidation of a South American bloc centered on Mercosur.

By the time of the Third Summit of the Americas in April 2001 in Quebec, in spite of the apparent collapse of Mercosur at the time, the Brazilian strategy, in great part because of the context explained above, was reasonably secured. As a new administration was inaugurated in the United States that openly proclaimed its commitment to free trade and to the establishment of the FTAA, the process of consolidation of a South American space had already been set in motion. ${ }^{7}$ As the preparations for the Quebec meeting began in 2000, Brazil launched a historic initiative: it brought all of South America's leaders together for the first

6 As Jeffrey Schott remarks: "When US-Mexico free trade talks were first broached in 1990, few realized how closely integrated the two economies already were, or how closely US interests coincided with the promotion of economic growth and political stability in the region" (Schott 2001, 93-94).

7 Indeed, the George W. Bush administration came to Quebec willing to move up the deadline for the FTAA to 2003 from 2005 . 
time to a conference in Brasília in order to discuss a variety of issues pertaining to that regional subsystem. The significance of this event was that it was the first exclusive meeting of all South American presidents. The Mexican president, like every other Latin American leader outside South America, was not invited for the summit and declared that he "would like to have been invited," adding that "our geographical situation in North America in any way impedes us from having an intense relationship with Latin America" (Veja 2000, 49). Yet, this was not to be another "Latin American" meeting, but explicitly a South American one. It was a concrete symbol of the realization that South America was in fact a distinct regional subsystem, one in which Brazil played a central role. As Sean Burges commented, the 2000 meeting was "the first exclusive gathering of South American presidents, giving symbolic gravitas to South America as a viable geopolitical entity" and its outcome suggested "an implicit acceptance of the consensual leadership role that Brazil had been accruing over the previous six years” (Burges 2009, 59).

For Burges, who places particular emphasis on the abovementioned concept of "consensual leadership," this kind of leadership is based not on "coercion or imposition" but on "coordination, consultation, and discussion" (Burges 2009, 54). Since it requires fewer resources than relying on coercion, it is particularly fitted for a country that occupies a key position in its region but at the same time has limited power resources, as is the case of Brazil. The concept alluded to by Burges is based on the notion of "cooperative hegemony" developed by Thomas Pedersen. In contrast to the hegemonic stability theory, which focuses only on powerful states, the cooperative hegemony approach "centres around the proposition that major states which are militarily weak or weakened may seek to maximise or stabilise their influence through non-coercive means by pursuing a strategy of co-operative hegemony within a multilateral structure" (Pedersen 2002, 696). ${ }^{8}$ Thus, Pedersen's theory of cooperative hegemony seeks to explain the formative processes of regional institutionalization based on the long-term strategies of major regional powers, while at the same time it highlights the importance of geopolitical and security elements, rather than economic factors, leading to regional institutionalization. A key element of the grand strategy of cooperative hegemony is what Pedersen denominates "power aggregation capacity," which "refers to the capacity of a regional big power to make a number of neighbouring states rally around its political project." The author adds that even though "this capacity is constrained by external structural factors at the regional and global level, it also depends upon psychological factors and leadership skills" (ibid., 689). Pedersen's cooperative hegemony approach provides a particularly appropriate framework to understand the role of Brazil during the FTAA negotiations, which became especially evident after the year 2000 .

8 For the hegemonic stability theory see Keohane (1984) and Gilpin (1981). 
By bringing together all twelve presidents of South America to Brasília, the Brazilian government officially signaled its attempt to rally the South American states around Brazil's political project of organizing a South American space as a means of inserting the region in the post-Cold War international system. President Cardoso described the 2000 summit as a "moment of reaffirmation of South America's identity as a region" adding that a "free trade agreement between Mercosur and the Andean Community will be the dorsal spine of South America as an extended economic space." Therefore, he concluded, "it should be seen as a political objective of immediate concern" (Cardoso 2000). These statements make plainly clear the goal as well as the means to accomplish it. The immediate goal was the construction of South America as a distinct economic and political space. In order to achieve it, it was necessary to act in two dimensions - at the ideational level, it was essential to affirm a South American identity, while at the practical level it was necessary to merge Mercosur and the Andean Community, which was the second major trading bloc in South America and at the time included Bolivia, Peru, Ecuador, Colombia, and Venezuela. This Brazilian proposal-which was clearly an upshot of the original scheme of a South American Free Trade Area unveiled almost a decade before-is especially significant if considered within the context of the acute crisis that Mercosur was going through at the time, as pointed out above.

The principle behind this policy was consistently supported by the administrations that preceded Cardoso as well as by the administrations that have succeeded him. In fact, the administration of Lula da Silva, which was inaugurated in 2003, saw the integration of South America as a top foreign policy priority and in 2004, during the third meeting of South American presidents in Peru, Mercosur and the Andean Community formalized a cooperation agreement thus creating the "South America Community of Nations," which later became the "Union of South American Nations," or Unasur. In May 2008, the Unasur countries met in Brasília to sign its constitutive treaty, establishing its juridical and political components and including the Brazilian proposal of a South American Defense Council. The Brazilian Defense Minister, when asked on a visit to Washington how the United States could help, said that the best way the United States could collaborate would be to "watch from the outside and keep its distance" (Catanhede 2008). Colombia, which has had strong military ties with the United States and was then in the middle of an acute diplomatic crisis with Venezuela and Ecuador, was the only country not to sign the pact that created the Defense Council. However, after intense negotiations led by Brazil and a growing fear of political isolation in the region, Colombia decided to join the Council a couple of months later (Jardim 2008). In 2009, the South American Defense Council held its first meeting in Santiago, Chile, and was attended by all Defense Ministers of the region. The main significance of this body is that it excludes the United States and overlaps with functions that were previously performed by hemispheric bodies such as the 
Organization of American States (OAS). In particular, it represents a challenge to the security counterpart of the FTAA launched at the 1994 Miami Summit: the Defense Ministerial of the Americas, which assembled for the first time in 1995, in Williamsburg, Virginia, and have met roughly every two years since then in different countries. ${ }^{9}$

By explicitly articulating the concept of a South America as a distinct regional subsystem, successive Brazilian administrations after the end of the Cold War were basically recuperating a recurrent theme of Brazil's foreign policy that was present since the early days of independence: the notion that in contrast to the rest of Latin America, where Brazil would seek not to get involved and would-sometimes tacitly, sometimes explicitly-recognize US preeminence, South America was understood by Brazilian policy makers as being a Brazilian sphere of influence where US interference should be kept at arm's length since it could easily overtake Brazil as the predominant player in the region. The meeting of South American Presidents in 2000 made explicit the concept of South America once again as a key component of Brazilian diplomacy, a reality that turned out to be even more salient during the Lula da Silva administration. One noteworthy change that was marked by the 2000 meeting was that, while initially the Brazilian view of South America had been mostly restricted to the Southern Cone, now it unequivocally incorporated the northern-tier countries of South America, including Guiana and Suriname (Cardoso 2000).

Consequently, by the time the Bush administration finally got fast track authority from Congress in 2002, the Brazilian strategy was already clearly underway. Between 1994 and 2002, the years that US administrations had no fast track and therefore could not provide clear leadership to the FTAA process, Brazil had achieved its goal of forging a South American bloc by using Mercosur as an alternative hub to NAFTA with reasonable success, and was also in the process of bringing Argentina closer to the Brazilian camp. With this basic framework in place, Brazil could shift the focus away from the US lack of fast track and concentrate on more substantive issues such as agriculture liberalization, particularly regarding non-tariff barriers, which had been a focal point of disagreement between the United States and Brazil throughout the negotiations. Again, the United States helped the Brazilian case by providing the necessary ammunition when the US Congress passed a US $\$ 100$ billion farm bill that significantly increased agricultural subsidies in the same year that President Bush got fast track authority, in 2002 (Becker 2002). The passing of the 2002 farm bill signaled the US unwillingness to liberalize a sector that was central to Brazilian interests in the FTAA and allowed President Cardoso to frame the United States, and not Brazil, as the real problem

9 After Williamsburg, the Defense Ministerial of the Americas met in Bariloche, Argentina (1996); Cartagena, Colombia (1998); Manaus, Brazil (2000); Santiago, Chile (2002); Quito, Ecuador (2004); Managua, Nicaragua (2006); Banff, Canada (2008); and Santa Cruz de la Sierra, Bolivia (2010). Uruguay will host the tenth meeting, in 2012 . 
for the establishment of hemispheric free trade (Rompay 2004, 128). In addition, the Bush administration after September 2001 was primarily focused on the Middle East, which dominated the US domestic political debate at the time.

Within this context, the results of a ministerial meeting in Miami in 2003, at the final phase of the FTAA negotiations, was considered a Brazilian victorythe final outcome of Miami was termed as a "FTAA à la carte" or a "FTAAlight," that is, a non-comprehensive FTAA with different levels of commitment (Romero 2003). The Ministerial Declaration of Miami stated that the "Ministers recognize that countries may assume different levels of commitments" and that the "negotiations should allow for countries that so choose, within the FTAA, to agree to additional obligations and benefits" (Ministerial Declaration 2003). These statements meant that the notion that the FTAA should be negotiated as a comprehensive "single undertaking," which was a basic principle until then, had come to an end. Each country was free to negotiate which areas to put in a FTAA agreement and with the interests of the United States and Brazil "very much at opposite ends of the spectrum," (since the first was interested mainly on liberalization on services and investments and the latter on the agricultural sector) they did not have any incentives to compromise (Stephenson 2008, 29). It was the beginning of the end of the FTAA.

As the American heads of state convened for the Fourth Summit of the Americas in Mar del Plata, Argentina, in 2005, the long process of FTAA agony that had become evident by the Miami Ministerial Declaration two years earlier came to an end. Since 2005 marked the original deadline for a final agreement on the FTAA and no agreement was eventually reached, the ailing FTAA was virtually buried in Mar del Plata. The 2005 summit was a perfect illustration of how Mercosur was efficiently used by Brazil as the core of its strategy to fend off the establishment of a hemispheric free trade area. Among the thirty-four participants of the summit, twenty-nine were in favor of moving forward on the FTAA negotiations. The five dissenting nations were composed by the four full members of Mercosur plus Venezuela, which a month later was officially invited to join Mercosur as a full member. It is noteworthy that these five nations together represent about 75 percent of the total GDP of South America. With the possibility of a comprehensive hemispheric agreement out of the table, and with the Trade Promotion Authority in hand, the Bush administration sought to establish bilateral free trade agreements with individual countries, including Chile, Peru, Colombia, and Ecuador, at the same time that Brazil sought to establish South America as an "extended economic space," as President Cardoso had declared at the beginning of the decade. The biggest difference between the two strategies seems to be that while the United States relies on specific and detailed agreements with individual countries, Brazil seeks a higher degree of multilateral institutionalization through a regional framework coupled with the attempt to construct a South American identity. These two approaches seem to be "on a collision course" (Stephenson 
$2008,41)$ and point toward a situation of what Henry Kissinger $(2001,98)$ had termed at the beginning of the last decade as a "tacit competition" between Brazil and the United States in South America since the end of the Cold War.

\section{Conclusion}

The process involving the rise and fall of the FTAA negotiations is a clear illustration of Brazil's regional strategy of keeping the United States at arm's length in South America. As Brazil perceived the United States as competing with its goal of keeping the status quo in the South American regional subsystem, the Brazilian approach gradually moved from estrangement to the institutionalization of the South American space through the strategy of cooperative hegemony. This was done through intense participation in the FTAA process, even though Brazil had clearly no enthusiasm for it, while in parallel leading the formation of a South American bloc by creating political and economic incentives that in many ways competed with the FTAA goals. Whereas the United States sought to use an extended NAFTA as a continental base from which it would lead the post-Cold War world, Brazil sought to build a South American platform organized around Mercosur. Because these two objectives tended to collide, both the United States and Brazil saw each other's project as a threat to their own policies from the beginning.

As it turned out, in spite of the disparities in power between the United States and Brazil, time was on the latter's side. Domestic and regional subsystemic pressures tended to favor the maintenance of the status quo, and all Brazil had to do was work to delay the conclusion of the FTAA in order to give time for these pressures to make themselves felt. Whereas the launching of the FTAA negotiations reflected the weight of US power in the hemisphere, the actual interactions among the American states following the Miami Summit in 1994 made power discrepancies less relevant to the outcome of the negotiations. In fact, in a matter of four years, between the Miami Summit in 1994 and the Santiago Summit in 1998 , it became clear that two poles of attraction were being constituted in the hemisphere-one centered on the United States-NAFTA core and the other centered on Brazil-Mercosur. Focusing on the international system and on power imbalances would be of little help to explain this configuration. In order to provide an effective explanation for this outcome, it is necessary to take into account the interplay between domestic and regional subsystemic dynamics.

Domestically, the difficulties of the Clinton administration in obtaining fast track authority to negotiate the FTAA made it clear that the United States was not willing to pay the costs of regional subsystemic change. This lack of effective leadership was a key element in enabling Brazil to push its agenda in South America more successfully. The case of Chile, which had gone from considering NAFTA 
membership to embracing Mercosur, provides a clear illustration of this claim. In regional subsystemic terms, the outbreak of the economic crises first in Mexico and later in Argentina acted as catalysts that helped to set in motion regional subsystemic dynamics by bringing closer together the two major actors of each regional subsystem - the United States and Mexico in North America, and Brazil and Argentina in South America. While the outcome of the Mexican crisis made it clear that NAFTA had definitively North-Americanized Mexico, the Argentinean crisis contributed to the South-Americanization of Argentina's foreign policy.

These interactions favored the Brazilian strategy of consolidating a South American bloc around the Mercosur core, and when the United States eventually overcame some of its domestic obstacles as the US Congress granted fast track authority (then renamed Trade Promotion Authority) to the Bush administration in 2002, the original FTAA goals of a genuine hemispheric integration had lost much of its impulse. As a result, even with fast track authority in hands, the Bush administration was not able to conclude the FTAA by the original 2005 target date. The immediate consequence of the FTAA debacle was that the United States resorted to the establishment of bilateral trade agreements with individual countries in South America, while Brazil hoped to accelerate the process of institutionalization of the South American space, thus incorporating issues going beyond trade, such as security.

In contrast to the US strategy, which relies mostly on specific trade agreements and therefore is much more restricted, Brazil seems to pursue a strategy of cooperative hegemony in which it attempts, within a multilateral structure and by stressing a common identity, to make all South American states rally around the political project of establishing South America as a distinct region within the hemisphere, thus increasing the costs of a more significant US involvement in South America. The Brazilian strategy of leading a South American bloc seems to have been working so far, as indicated by a recent public opinion poll taken on eighteen Latin American countries which shows Brazil as being perceived as the country with greatest leadership in the region by $19 \%$ of the population in Latin America followed by the United States with 9\% (Latinobarometro 2010, 111). It is interesting to notice that the same report shows that $67 \%$ of the Latin American population sees the United States as a positive influence, contrasted to Brazil's 61\%, which seems to indicate that US numbers are not related to an anti-US feeling. Since Brazilian leadership perception decreases as one moves from Argentina to Mexico, when considering only the nine South American countries in the sample (excluding Brazil), Brazil's average goes up to around 27\%, with half of the Argentinean population indicating Brazil as the regional leader. ${ }^{10}$ These numbers seem to indicate that Brazilian strategy of cooperative hegemony has achieved a considerable degree of success. It remains to be seen how sustainable it will be.

10 In decreasing order of Brazil's leadership perception: Argentina, Uruguay, Paraguay, Chile, Colombia, Bolivia, Peru, Venezuela, and Ecuador. 


\section{Bibliographic references}

Atkins, G. Pope. Latin America and the Caribbean in the International System. 4th ed. Boulder, Colo.: Westview Press, 1999.

Bandeira, Moniz. As Relaçôes Perigosas: Brasil-Estados Unidos (de Collor a Lula, 1990-2004). Rio de Janeiro: Civilização Brasileira, 2004.

Becker, Elizabeth. "Accord Reached on a Bill Raising Farm Subsidies.” New York Times, April 27, 2002.

Bernier, Ivan, and Martin Roy. "Nafta and Mercosur: Two Competing Models?" In The Americas in Transition: The Contours of Regionalism, edited by Gordon Mace and Louis Bélanger, 69-91. Boulder, Colo.: Lynne Rienner Publishers, 1999.

Burges, Sean W. Brazilian Foreign Policy after the Cold War. Gainesville: University Press of Florida, 2009.

Cardoso, Fernando Henrique. "O Brasil e uma Nova América do Sul.” Valor Economico, August 30, 2000.

Cardoso, Fernando Henrique. Politica Externa em Tempos de Mudança : A Gestão do Ministro Fernando Henrique Cardoso no Itamaraty (5 de Outubro de 1992 a 21 de Maio de 1993) : Discursos, Artigos e Entrevistas. Brasília: Fundação Alexandre de Gusmão, 1994.

Cardoso, Fernando Henrique, and Roberto Pompeu de Toledo. O Presidente Segundo o Sociólogo: Entrevista de Fernando Henrique Cardoso a Roberto Pompeu de Toledo. São Paulo: Companhia das Letras, 1998.

Carranza, Mario E. "Can Mercosur Survive? Domestic and International Constraints on Mercosur." Latin American Politics and Society 45, no. 2 (2003): 67-103.

Carranza, Mario E. "Mercosur and the End Game of the FTAA Negotiations: Challenges and Prospects after the Argentine Crisis." Third World Quarterly 25, no. 2 (2004): 319-37.

Carranza, Mario E. South American Free Trade Area or Free Trade Area of the Americas? : Open Regionalism and the Future of Regional Economic Integration in South America, Political Economy of Latin America. Aldershot, England ; Burlington, USA: Ashgate, 2000.

Catanhede, Eliane. "EUA Ajudam Quando Ficam Longe, Diz Jobim.” Folha de Sao Paulo, March 22, 2008.

Cervo, Amado Luiz, and Clodoaldo Bueno. História da Política Exterior do Brasil. 3 ed. Brasília: Editora UnB, 2008.

Domínguez, Jorge I., and Rafael Fernández de Castro. The United States and Mexico : Between Partnership and Conflict. 2nd ed. New York: Routledge, 2009.

Fauriol, Georges A., and William Perry. Thinking Strategically About 2005: The United States and South America. Washington, DC: Center for Strategic and International Studies, 1999.

Feinberg, Richard E. Summitry in the Americas: A Progress Report. Washington, D.C.: Institute for International Economics, 1997.

Franko, Patrice M. Toward a New Security Architecture in the Americas : The Strategic Implications of the FTAA. Washington, D.C.: Center for Strategic and International Studies, 2000.

Gilpin, Robert. War and Change in World Politics. Cambridge ; New York: Cambridge University Press, 1981. 
Haggard, Stephan. "The Political Economy of Regionalism in the Western Hemisphere." In The Post-Nafta Political Economy: Mexico and the Western Hemisphere, edited by Carol Wise, 302-38. University Park, Penn.: The Pennsylvania State University Press, 1998.

Handelman, Stephen. "Special Report: Summit of the Americas." Time, April 19, 2001.

Hirschman, Albert O. National Power and the Structure of Foreign Trade. Berkeley and Los Angeles: University of California press, 1945.

Hirst, Mônica. "Mercosur's Complex Political Agenda." In Mercosur: Regional Integration, World Markets, edited by Riordan Roett, 35-47. Boulder, Colo.: Lynne Rienner, 1999.

Hurrell, Andrew. "Regionalism in the Americas." In Regionalism in World Politics : Regional Organization and International Order, edited by Louise L'Estrange Fawcett and Andrew Hurrell, xiii, 342 p. New York: Oxford University Press, 1995.

Interamerican Development Bank. "Dataintal - Comércio Bilateral." Availability: <http://www. iadb.org/dataintal/>, accessed February 1, 2011.

Jardim, Claudia. "Colômbia Adere a Conselho de Defesa Sul-Americano.” BBC Brasil, July 19, 2008. Availability: <http://www.bbc.co.uk/portuguese/reporterbbc/story/2008/07/080719_ lulauribeconselho_cj_cg.shtml>, accessed February 13, 2011.

Katzenstein, Peter J. A World of Regions : Asia and Europe in the American Imperium, Cornell Studies in Political Economy. Ithaca, N.Y.: Cornell University Press, 2005.

Keohane, Robert O. After Hegemony : Cooperation and Discord in the World Political Economy. Princeton, N.J.: Princeton University Press, 1984.

Keohane, Robert O., and Joseph S. Nye. Power and Interdependence: World Politics in Transition. Boston: Little, Brown, 1977.

Kissinger, Henry. Does America Need a Foreign Policy? : Toward a Diplomacy for the 21st Century. New York: Simon \& Schuster, 2001.

Lampreia, Luiz Felipe. O Brasil e os Ventos do Mundo: Memórias de Cinco Décadas na Cena Internacional. Rio de Janeiro: Objetiva, 2010.

Latinobarómetro. “Anual Report 2010.” Santiago: Latinobarómetro Corporation, 2010.

Mayer, Frederick. Interpreting Nafta: The Science and Art of Political Analysis. New York: Columbia University Press, 1998.

Mera, Laura Gomez. "Explaining Mercosur’s Survival: Strategic Sources of Argentine-Brazilian Convergence." Journal of Latin American Studies 37, no. 1 (2005): 109-40.

Ministerial Declaration: Free Trade Area of the Americas. Miami. "F.T.A.A. Eighth Ministerial Meeting." November 20, 2003. Availability: <http://www.ftaa-alca.org/ministerials/miami/ Miami_e.asp>, accessed February 10, 2011.

Munck, Ronaldo. "The Democratic Decade: Argentina since Malvinas." Bulletin of Latin American Research 11, no. 2 (1992): 205-16.

New York Times. "Aid for Mexico Gives Economy Shot in the Arm.” February 2, 1995.

Munck, Ronaldo. "Negotiators Fail to Agree on Free Trade Proposal at Americas Summit." November 6, 2005.

O'Keefe, Thomas Andrew. Latin American and Caribbean Trade Agreements : Keys to a Prosperous Community of the Americas. Leiden: Martinus Nijhoff Publishers, 2009. 
Pedersen, Thomas. "Cooperative Hegemony: Power, Ideas and Institutions in Regional Integration.” Review of International Studies 28, no. 4 (2002): 677-96.

Petras, James. "U.S. Offensive in Latin America: Coups, Retreats, and Radicalization.” Monthly Review 54, no. 1 (2002): 15.

Phillips, Nicola. "Hemispheric Integration and Subregionalism in the Americas." International Affairs (Royal Institute of International Affairs 1944-) 79, no. 2 (2003): 327-49.

Preusse, Heinz G. "The Future of Mercosur." In Free Trade in the Americas: Economic and Political Issues for Governments and Firms, edited by Sidney Weintraub, Alan M. Rugman and Gavin Boyd, 127-52. Cheltenham, UK ; Northampton, Mass.: Edward Elgar, 2004.

Roett, Riordan. "U.S. Policy toward Mercosur: From Miami to Santiago." In Mercosur : Regional Integration, World Markets, edited by Riordan Roett, 111-24. Boulder, Colo.: Lynne Rienner, 1999.

Rohter, Larry. "Argentina and the U.S. Grow Apart over a Crisis." New York Times, January 20, 2002.

Rohter, Larry. "Free Trade Goes South with or without U.S.” New York Times, January 6, 1997.

Rohter, Larry. "South American Trade Bloc under Siege.” New York Times, March 24, 2001.

Romero, Simon. "Hemisphere Trade Talks in Miami Are Reported to Hit a Bump." New York Times, November 17, 2003.

Rompay, Jan van. "Brazil's Strategy Towards the FTAA." In Free Trade for the Americas?: The United States' Push for the FTAA Agreement, edited by Paulo Gilberto Fagundes Vizentini and Marianne Wiesebron, 120-48. London ; New York: Zed Books, 2004.

Rugman, Alan M. "Economic Integration in North America: Implications for the Americas." In Free Trade in the Americas : Economic and Political Issues for Governments and Firms, edited by Sidney Weintraub, Alan M. Rugman and Gavin Boyd, 90-126. Cheltenham, UK ; Northampton, Mass.: Edward Elgar, 2004.

Schott, Jeffrey J. Prospects for Free Trade in the Americas. Washington, DC: Institute for International Economics, 2001.

Smith, Joseph. Brazil and the United States: Convergence and Divergence, The United States and the Americas. Athens: University of Georgia Press, 2010.

Stephenson, Sherry M. "New Trade Strategies in the Americas." In Economic Integration in the Americas, edited by Joseph A. McKinney and H. Stephen Gardner, 27-45. London ; New York: Routledge, 2008.

Stratfor. "Members' Policies Spell Mercosur’s Demise." October 10, 2001. Availability: <http:// www.stratfor.com/memberships/3653/analysis/members_policies_spell_mercosurs_demise>, accessed February 9, 2011.

Sweeney, John. "Clinton's Latin America Policy: A Legacy of Missed Opportunities." The Heritage Foundation, July 6, 1998. Availability: <http://www.heritage.org/research/ reports/1998/07/clintons-latin-america-policy>, accessed February 8, 2011.

Tokatlian, Juan Gabriel. "Politica Exterior Argentina de Menem a de La Rua: La Diplomacia del Ajuste." Escenarios Alternativos 4, no. 9 (2000).

Veja. "O Brasil Diz Não." September 6, 2000, 42-49. 
Vizentini, Paulo Gilberto Fagundes. "The FTAA and US Strategy: A Southern Point of View.” In Free Trade for the Americas?: The United States' Push for the FTAA Agreement, edited by Paulo Gilberto Fagundes Vizentini and Marianne Wiesebron, 11-22. London ; New York: Zed Books, 2004.

Weintraub, Sidney. Development and Democracy in the Southern Cone: Imperatives for U.S. Policy in South America, Significant Issues Series V. 22, No. 1. Washington, D.C.: Center for Strategic and International Studies, 2000.

Whitt Jr, Joseph A. “The Mexican Peso Crisis.” Economic Review 81, no. 1 (1996).

Received June $13^{\text {th }}, 2011$

Accepted June $23^{\text {rd }}, 2011$

\begin{abstract}
This article argues that Brazil went from a posture of estrangement in relation to the hemispheric project represented by the Free Trade Area of the Americas (FTAA) to a strategy of cooperative hegemony aimed at institutionalizing the South American space and increasing the costs of the FTAA for the United States. Although Brazil was initially isolated, US lack of leadership combined with events at the subregional level ended up turning the tide in the direction of Brazilian interests. These factors help to understand the current institutional configuration of South America.
\end{abstract}

Keywords: Brazilian Foreign Policy; FTAA; South America.

\title{
Resumo
}

Este artigo argumenta que o Brasil passou de uma postura de desavença em relação ao projeto hemisférico representado pela Área de Livre Comércio das Américas (Alca) para uma estratégia de cooperação hegemônica visando a institucionalizar o espaço sul-americano e aumentar os custos da Alca para os Estados Unidos. Apesar de o Brasil ter estado inicialmente isolado em sua posição, a falta de liderança norte-americana combinada com eventos no nível sub-regional acabaram por criar uma situação favorável aos interesses brasileiros. Tais fatores ajudam a compreender a atual configuração institucional da América do Sul.

Palavras-chave: Política Externa Brasileira; Alca; América do Sul. 